DOI: $h$ ttps://doi.org/10.31933/dijemss.v2i2 Received: $18^{\text {th }}$ October 2020, Revised: $25^{\text {th }}$ November 2020, Publish: $20^{\text {th }}$ December 2020

\begin{tabular}{|c|c|c|}
\hline PINASTISHER & $\begin{array}{l}\text { DIJEMSS } \\
\text { DINASTI INTERNATIONAL JOURNAL } \\
\text { OF EDUCATION MANAGEMENT AND } \\
\text { SOCIAL SCIENCE }\end{array}$ & $\begin{array}{r}\text { https://dinastipub.org/DIJEMSS } \\
\text { editor@dinastipub.org } \\
08117401455 @\end{array}$ \\
\hline
\end{tabular}

\title{
HOW PRICE PERCEPTION AND TRUST AFFECTED MILLENIAL ONLINE BUYING INTEREST DURING COVID-19 PANDEMIC IN WEST JAVA
}

\author{
Harrie Lutfie ${ }^{1}$, Dandy Marcelino ${ }^{2}$ \\ ${ }^{1)}$ School of Applied Science, Telkom University, Bandung, Indonesia, harrie.lutfie@gmail.com \\ ${ }^{2)}$ School of Economy and Business, Telkom University, Bandung, Indonesia, dandy.marcel@gmail.com \\ Corresponding Author: Harrie Lutfie ${ }^{1}$
}

\begin{abstract}
The implementation of Work From Home also has an impact on the trend of buying interest online. The trend of buying interest online is usually carried out by young consumers or can be called as millenials because they are the ones who use online facilities to fulfill their needs even though they are not in a Covid-19 condition. Interest in buying online is influenced by price perception and level of consumer trust. Aim of this research for find out the influence of price perceptions and consumer trust on online buying interest during the Covid-19 pandemic in millennial consumers in West Java. From the results of this study, it can be concluded that millennial consumers' online purchase interest during the COVID-19 outbreak was influenced by product price perceptions and millennial consumer confidence. These results indicate that efforts to increase interest in buying online can be done by first increasing millennial consumer confidence.
\end{abstract}

Keywords: price perception, consumer trust, purchase intention, online buying interest, covid-19 pandemic, millenial generation.

\section{INTRODUCTION}

The current global economic condition is faced with serious problems, the cause of which is none other than the corona virus (COVID-19). The spread of this virus is fairly fast and has reached several countries around the world. This virus has become a global pandemic, which will greatly impact economic stability, one of which is the business world. Indonesia, as one of the countries that has also experienced the Covid-19 pandemic since early March 2020, has felt a major impact in all sectors of life, especially the economic sector. The Covid-19 virus is so deadly that it attacks the respiratory tract and can easily be transmitted to anyone. This especially happens quickly to someone whose immune system is weak. Therefore, the government must think hard about how to anticipate the spread of the virus, including in the West Java region.

West Java positive cases are still increasing, with the number of positive cases increasing. Therefore West Java is also promoting instructions from the central government to implement several activities that must be carried out by the community to prevent Covid- 
19 transmission, including Work From Home or WFH (working from home, learning from home, worshiping from home, even activities learning to teach also from home online, using masks, diligently washing hands with soap, washing clothes immediately after each trip, eating nutritious food, consuming vitamin $\mathrm{C}$, basking in the hot morning sun, and maintaining distance between one person and another. or social distancing between 1-2 meters.

In connection with the existence of Work From Home or WFH and social distancing, the movement of the community in life becomes choked up because at Work From Home or WFH people cannot leave the house and with social distancing the community is strictly prohibited from engaging in activities that are gathering or grouping. Even though they must still fulfill their daily needs. This affects people's lives, including the economic sector. Many shops and places of sale and purchase are closed, making it difficult for people to make ends meet. The prohibition to leave the house makes the space for people to move narrower. In fact, at times like this, the need for life is increasing. To overcome this situation, many people are starting to look to do online shopping because besides not having to leave the house, now many living necessities are sold online.

The implementation of Work From Home (WFH) also has an impact on the trend of buying interest online. The trend of buying interest online is usually carried out by young consumers or can be called as millenials because they are the ones who use online facilities to fulfill their needs even though they are not in a Covid-19 condition. The majority of them are classified as active in using the internet in searching for products or services online through various e-commerce platforms available in Indonesia, such as Tokopedia, Bukalapak, Shopee, Blibli, Lazada, and so on. Along with the development of online shopping and the development of current lifestyles, there has been a phenomenon of online shopping behavior among teenagers. The adolescent age group is an age that is currently in a transition period of development, between childhood to adulthood (Santrock, 2007). The shopping behavior favored by teenagers is currently hedonic shopping, where the lives of teenagers tend to prefer and prioritize mere pleasure when shopping online. But under current conditions, with the Covid-19 trend of online purchases not only made by teenagers but also all age groups to meet their needs.

Apart from need, interest in buying online is influenced by several factors, which include price, level of trust, flexibility in time, and various products. Price is the main factor influencing online purchases. The more affordable the price of an item, the more interest in buying. Usually, the price of products offered online tends to be lower than offline, because online sales do not require rental fees, facility fees (such as electricity and water), and employee salary costs. The next factor is consumer trust which is the basis in a relationship between one party and another, which strengthens each other so that there is a mutually beneficial relationship. In the online buying and selling system, the trust factor is always a consideration because here the buyer cannot see the goods directly and the seller sometimes does not immediately receive payment. So there are no real transactions, only based on trust. If this factor does not exist, online buying and selling will never happen. Based on the above background, the authors are interested in knowing the extent of the influence of price perceptions and consumer trust on online buying interest during the Covid-19 pandemic in millennial consumers in West Java. 


\section{LITERATURE REVIEW Price Perception}

Kusdyah (2012) states that price perception becomes a consumer judgment about the comparison of the amount of sacrifice with what will be obtained from products and services. Lee et al. (2011: 532) argues that price perception is a consumer judgment and an associated emotional form regarding whether the price offered by the seller and the price contrasted with different gatherings is sensible, worthy or reasonable. According to Toncar et al. (2010: 297) states that consumer price perceptions are influenced by prices offered by other stores with the same goods.

The price perception in this study is the amount of money charged for the amount and value of products that consumers exchange for benefits that can be compared with other purchasing methods. Indicators of price perception according to Algesheimer et al. (2005: 54) are: 1) Affordable prices; 2) Attractive price promos such as discounts, free shipping; 3) Match price with quality; and 4) Payment method.

\section{Consumer Trust}

Leeraphong (2013) state that trust is an important factor, which makes consumers interested in buying online products. Marcelino (2020) said that trust in online shops is very important and the diversity of online interactions. From the results perceived by consumers, online shopping confidence affects purchase intentions through social media. According to Anwar and Adidarma (2016) in their research defining trust in online shopping as a compliance of consumers to trust online shopping. The trust factor is a key factor in every online sale and purchase, because the products sold and offered by the seller are pseudo products, in the sense that the product is still only a shadow, not a real form (Lutfie and Marcelino, 2020: 212).

Consumers 'perceptions of online retailers' consistency and honesty were found to be a strong influence on consumer trust in online shops (Rose et al., 2012). Trust in this study is a belief that arises in consumers about the products that will be obtained by purchasing online according to what is offered. Indicators of trust according to Abdurrahman (2012) are as follows: 1) Confidence in the satisfaction guarantee when buying online; 2) Attention to information about online purchases; 3) Transparency of information regarding online purchases.

\section{Purchase Intention}

In the marketing strategy, consumer behavior is a serious concern for producers or service providers, one of which is purchase intention (Saifudin, 2019: 149). Buy intention is something identified with purchaser intends to purchase certain items and the number of units of the item are required in a specific time span (Hasan, 2014: 173). Setiadi (2011: 216) states that purchase intention is framed from customer perspectives towards items which comprise of buyer trust in brands and brand assessment, so that from these two stages there is an interest in buying.

Purchasing interest in this research is someone's desire or plan to buy a product in a certain amount and time. The indicators of buying interest according to Hasan (2014: 173) are as follows: 1) Consistency in online purchasing; 2) Always seek information about online 
purchases; 3) Not looking for information about other methods of purchase; 4) The desire to make an online purchase; 5) Businesses referencing other people in online purchases; 6) An estimate of the satisfaction that will be obtained with an online purchase.

\section{The Relationship Between Price Perception and Consumer Trust}

Oppenheim and Ward (2006), clarify that the principle reason when individuals shop by means of the web is accommodation. They additionally concede that the past principle purpose behind shopping on the web was cost. Consumers consider prices is the main determinant of consumer trust on online stores, where someone's price perception will affect one's shopping trust. Thamizhvanan and Xavier (2013) in their research found that price perceptions have a significant influence on consumer trust. From the description above, the hypothesis that can be formed is:

H1: There is a possitive and significance effect between price perception and consumer trust.

\section{The Relationship Between Consumer Trust and Purchase Intention}

Setiadi (2011: 216) states that purchase intention is framed from shopper mentalities towards items which comprise of purchaser trust in brands and brand assessment, so that from these two stages there is an interest in buying. The higher the consumer's confidence, the higher the consumer's buying interest. Meanwhile, according to Koufaris and HamptonSosa (2004), purchaser trust in web based business is one of the key variables in purchasing and selling exercises on the web. Trust is considered an important factor and is one of the critical factors in stimulating online transactions. Mahkota (2014) stated that trust is able to generate positive consumer buying decisions. From the description above, the hypothesis that can be formed is:

H2: There is a positive and significance influence between consumer trust and purchase intention.

\section{The Relationship Between Price Perception and Purchase Intention}

Perceptions of price shopping orientation that are formed will influence consumer purchase intentions for a product (Taylor, 2009). According to Kim et al. (2011) online vendors can also create a balance of price and trust levels by giving different weights to the two. To do this, they need to know the relative importance of price and trust in the purchase decision. From the description above, the hypothesis that can be formed is:

H3: There is a positive and significance influence between price perception and purchase intention.

From the hypothetical examinations, past exploration results, and the detailing of theoretical study above, a theoretical frame of mind can be formed as follows: 


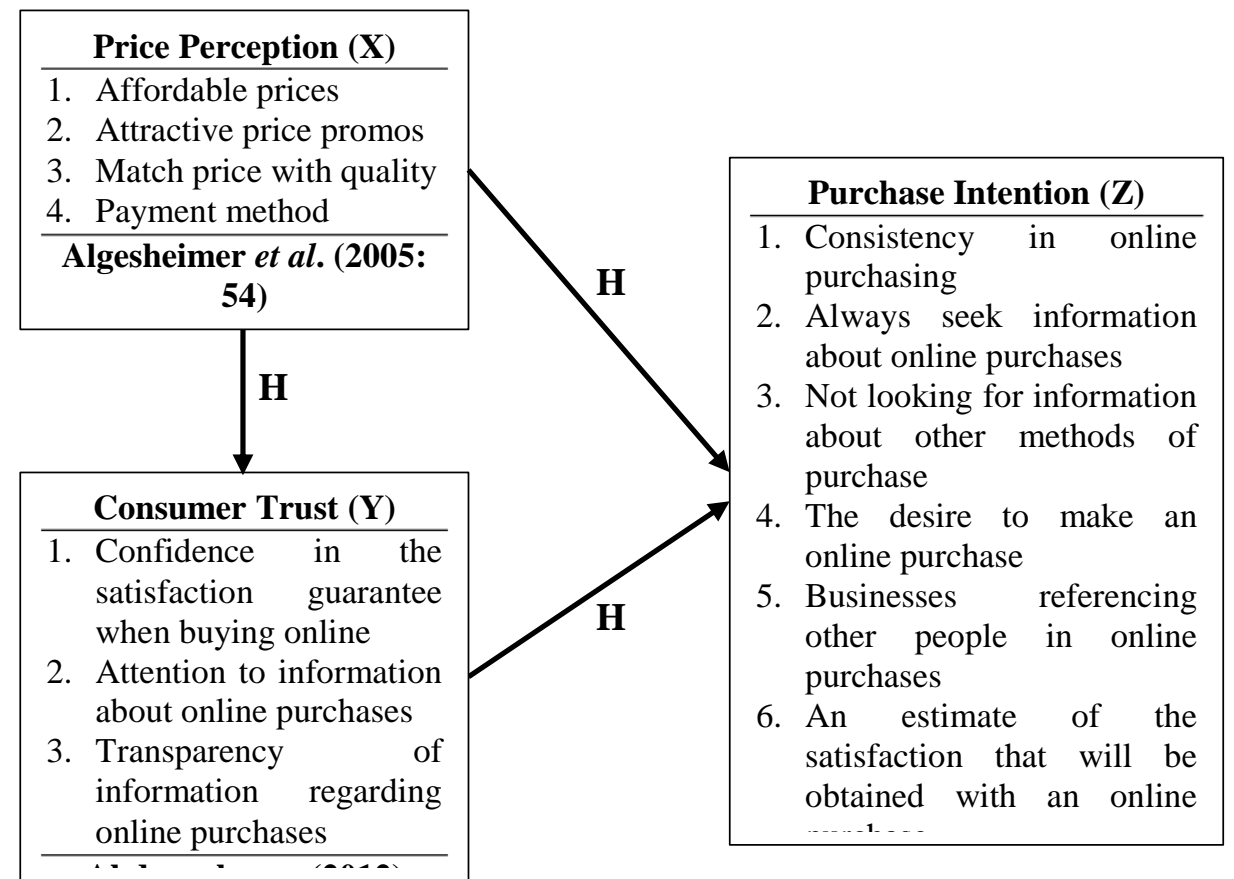

Figure 1. Research Framework Models

\section{RESEARCH METHODS}

This research type is illustrative exploration or clarification. The populace in this research were all millennials in West Java who used online purchasing facilities. Because of the difficulty in determining the number of populations that exist, the determination of sampling using convenience sampling method. Convenience sampling is carried out by selecting all millennials to be respondents without certain conditions. According to Zikmund et al. (2013: 356) because the number of population in this study is not known with certainty, the sampling technique used is the Bernoulli formula. In this study, using a level of accuracy ( $\alpha$ ) $5 \%$, and a confidence level of $95 \%$ so that according to sample count results, the number 384.16 is obtained for the minimum number of samples, the results are rounded up to 400 respondents to minimize errors when filling out the questionnaire.

To analyze the survey data, interpret the results of the study, structural equational model analysis techniques are used, for decide how much effect the perceived price has on buying interest online through consumer trust. According to Latan in Haryono and Wardoyo (2012: 9) that SEM is a second generation multivariate analysis technique that incorporates factor and path analysis, so as to allow researchers to test and estimate simultaneous relationship between exogeneous and endogenous multiple with multiple indicator. An important feature possessed by SEM is that of SEM using a linear model. The data collection technique was done through an online questionnaire. The measurement scale uses a Likert scale. Sources of data used are primary data, namely data obtained directly through questionnaires and secondary data obtained in the form of journals, articles and other reference books.

\section{FINDINGS AND DISCUSSION}

The SEM equation model can be divided into two types, namely SEM based on variants and SEM based on covariance. In this study using SEM based on variants. Variant-based SEM aims to process literacy or block variants between indicators or parameters that are 
estimated in one latent variable and do not correlate indicators between other latent variables in one research model. Partial Least Square (PLS) is a variation based auxiliary condition examination (SEM) that can at the same time perform estimation model testing just as basic model testing and is a causality prediction tool used for theory development.

\section{Measurement/Outer Model Test}

To test the measurement model (outer model), it is done by testing the validity and reliability of the indicators used in research with the SmartPLS 2 software to obtain accurate calculation results. The following is a model for testing the outer model.

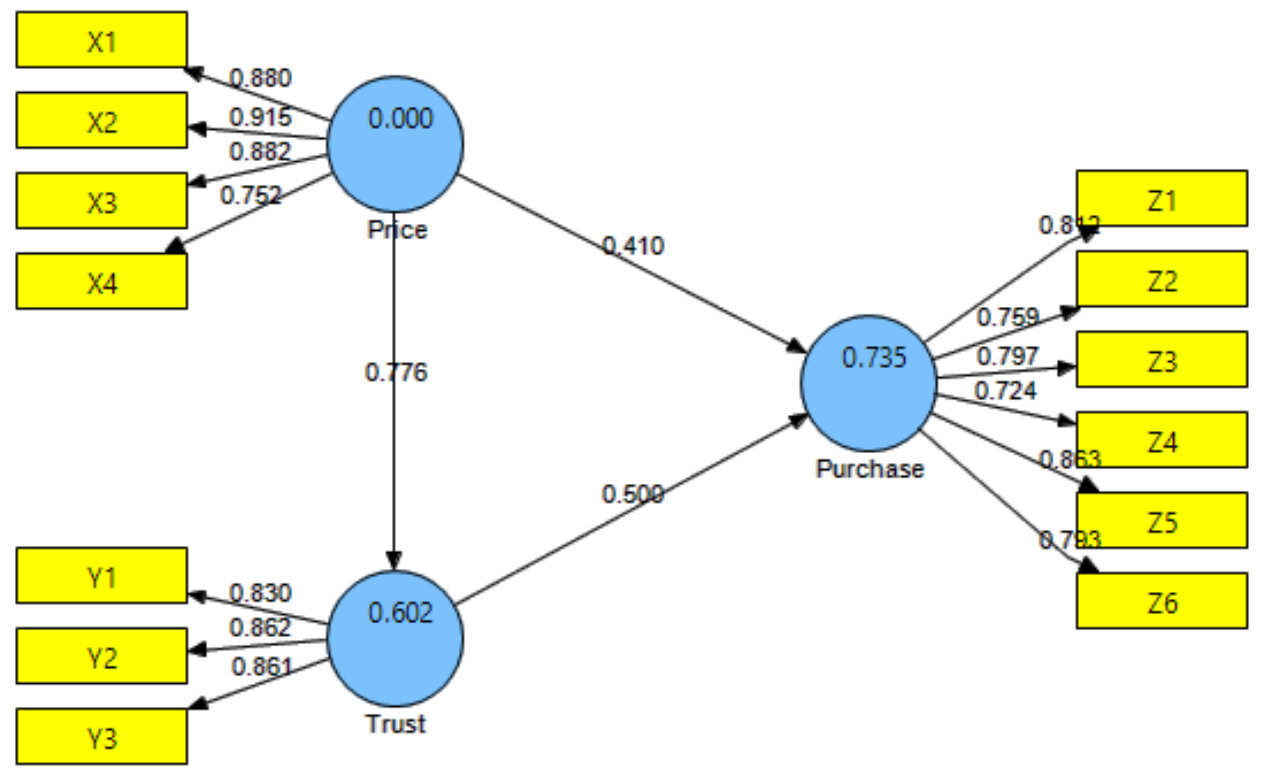

Figure 2. SEM Outer Model

The approach taken in this study begins with the measurement model (outer model), which is to analyze the construct validity of all variables, so that the indicators that form the construct are valid ones. After that, the next step is carried out, namely testing the structural model as a whole. Data obtained from the results of distributing questionnaires to respondents must be tested for validity and reliability first. The validity test was conducted to determine the ability of the research instrument to measure what it should be measured. In this study, using a construct validity test that shows how good the results obtained from using a measurement are in accordance with the theories that are used to define a construct. The construct variables consist of convergent validity and discriminant validity. In the construct validity test in general, it can be measured by the loading score parameter and using the AVE parameter. AVE score must be $>0.5$ and for loading score it must be $>0.5$. If the loading score is $<0.5$, this indicator can be removed from its construct because this indicator is not loaded into a representative construct. However, if the loading score is between $0.5-0.7$, the researcher should not delete the indicator that has this loading as long as the AVE score of the indicator is $>0.5$. The convergent validity test can be measured through the Average Variance Extracted (AVE) value and outer loading calculated by SmartPLS. The size of the 
outer loading value $>0.7$ indicates that the indicator in a variable has sufficient convergent validity. The following is the result of the outer model shown in the following table.

Table 1. Convergent Validity Test Result

\begin{tabular}{|c|c|c|c|}
\hline $\begin{array}{c}\text { Laten } \\
\text { Variable }\end{array}$ & Indicators & Results & Conclusion \\
\hline & Affordable prices & 0,8800 & Valid \\
\hline Price & Attractive price promos & 0,9150 & Valid \\
\hline \multirow[t]{2}{*}{ Perception } & Match price with quality & 0,8819 & Valid \\
\hline & Payment method & 0,7517 & Valid \\
\hline \multirow{3}{*}{$\begin{array}{c}\text { Consumer } \\
\text { Trust }\end{array}$} & Confidence in the satisfaction guarantee when buying online & 0,8301 & Valid \\
\hline & Attention to information about online purchases & 0,8617 & Valid \\
\hline & Transparency of information regarding online purchases & 0,8607 & Valid \\
\hline \multirow{6}{*}{$\begin{array}{l}\text { Purchase } \\
\text { Intention }\end{array}$} & Consistency in online purchasing & 0,8120 & Valid \\
\hline & Always seek information about online purchases & 0,7586 & Valid \\
\hline & Not looking for information about other methods of purchase & 0,7974 & Valid \\
\hline & The desire to make an online purchase & 0,7240 & Valid \\
\hline & Businesses referencing other people in online purchases & 0,8629 & Valid \\
\hline & Estimate of satisfaction that will be obtained with online buy & 0,7928 & Valid \\
\hline
\end{tabular}

The table above shows that the outer loading results obtained have a value $>0.5$, which means that overall it can be declared valid. Convergent validity test with Average Variance Extractea (AVE) value calculated by SmartPLS. The size of the AVE value $>0.5$ which indicates that the indicators in a variable have sufficient convergent validity. After carrying out the convergent validity test, the discriminant validity test is then carried out. Discriminant validity happens when two unique instruments measure two develops that are anticipated to be uncorrelated bringing about a score that isn't associated. The discriminant legitimacy test is surveyed dependent on the cross stacking of the measure with its develop. The following are the results of the discriminant validity test.

Table 2. Discriminant Validity Test Result

\begin{tabular}{|c|c|c|c|c|}
\hline Indicators & $\begin{array}{c}\text { Price } \\
\text { Perception }\end{array}$ & $\begin{array}{c}\text { Consumer } \\
\text { Trust }\end{array}$ & $\begin{array}{l}\text { Purchase } \\
\text { Intention }\end{array}$ & Conclusion \\
\hline Affordable prices & $\mathbf{0 , 8 8 0 0}$ & 0,7095 & 0,7450 & Valid \\
\hline Attractive price promos & 0,9150 & 0,7339 & 0,7162 & Valid \\
\hline Match price with quality & 0,8819 & 0,6825 & 0,6581 & Valid \\
\hline Payment method & 0,7517 & 0,5192 & 0,6149 & Valid \\
\hline $\begin{array}{l}\text { Confidence in satisfaction guarantee when buy } \\
\text { online }\end{array}$ & 0,6415 & $\mathbf{0 , 8 3 0 1}$ & 0,6732 & Valid \\
\hline Attention to information about online purchases & 0,6278 & 0,8617 & 0,6662 & Valid \\
\hline Transparency of information regarding online buying & 0,7059 & $\mathbf{0 , 8 6 0 7}$ & 0,7430 & Valid \\
\hline Consistency in online purchasing & 0,6804 & 0,6658 & $\mathbf{0 , 8 1 2 0}$ & Valid \\
\hline Always seek information about online purchases & 0,5692 & 0,5656 & 0,7586 & Valid \\
\hline $\begin{array}{l}\text { Not look for information about other purchase } \\
\text { method }\end{array}$ & 0,5892 & 0,6261 & 0,7974 & Valid \\
\hline The desire to make an online purchase & 0,5092 & 0,5873 & 0,7240 & Valid \\
\hline Businesses referencing other people in online buying & 0,7521 & 0,7364 & 0,8629 & Valid \\
\hline Estimate of satisfaction that obtained with online buy & 0,6572 & 0,6852 & 0,7928 & Valid \\
\hline
\end{tabular}


In the table above, it can be seen that the results of the discriminant validity test through cross loading show that the items that are declared valid because the indicator has the greatest cross loading value on that variable. Individual reflexive measures are said to be high if they correlate more than 0.7 with the construct to be measured. However, for research in the early stages of developing a measurement scale the loading value of 0.5 to 0.6 is considered sufficient. In addition to the validity test, this research also conducted a reliability test. Reliability test is used to show the accuracy, consistency and accuracy of a measuring instrument in making measurements. To determine the reliability of this study, testing was carried out by assessing Cronbach's alpha and composite reliability of each construct. Cronbach's alpha is used to measure the lower limit of the reliability value of a construct, while composite reliability is used to measure the real value of the reliability of a construct. The item is declared reliable if the Cronbach's alpha value is $>0.6$ and the composite reliability value must be $>0.7$. The following are the results of the reliability test.

Table 3. Reliability Test Result

\begin{tabular}{cccc}
\hline Laten Variable & Composite Reliability & Cronbachs Alpha & Conclusion \\
\hline Price Perception & 0,9183 & 0,8803 & Reliable \\
Consumer Trust & 0,8873 & 0,8097 & Reliable \\
Purchase Intention & 0,9099 & 0,8810 & Reliable \\
\hline
\end{tabular}

The table above shows that the results of the reliability test in this study can be said to be reliable because the Cronbach's alpha value is $>0.6$ so that it can be used as a variable measuring instrument in this study.

\section{Measurement/Inner Model Test}

The structural model in PLS can be measured using the R-Square for the dependent construct, Q-square for predictive relevance and Path Coefficients (t-count) to show the level of significance in hypothesis testing in research with SmartPLS software to obtain accurate calculation results. The following is a path diagram of the inner model carried out through the bootstrapping process in this study.

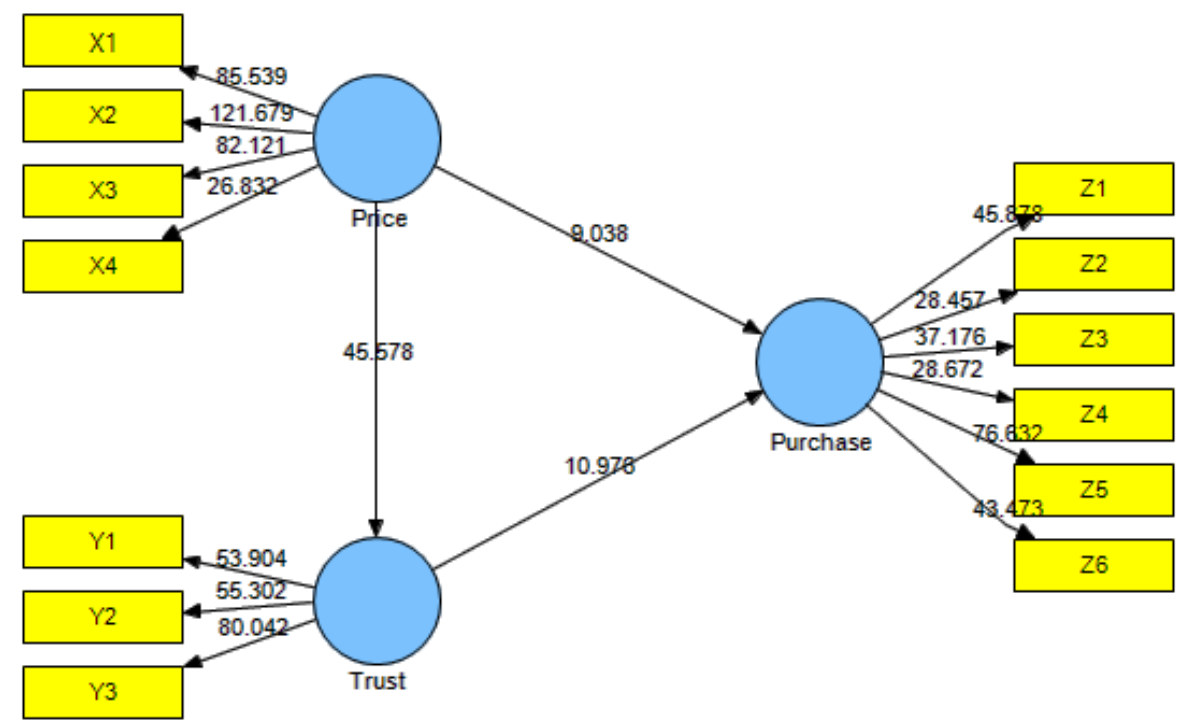

Figure 3. SEM (Structural Equation Modelling) Inner Model 
From the calculation results above, the value, to see whether the independent variable has no effect and how the direction of the relationship can be seen through the t-value and the path coefficients they have. The path coefficients score represented by the t-count must be above 1.96 for the two-tailed hypothesis. The following table shows the path coefficients and the t-value, namely.

Table 4. Hypothesis (t-Test) Result

\begin{tabular}{|c|c|c|c|c|c|c|c|}
\hline $\begin{array}{c}\text { Variable } \\
\text { Relationship } \\
\end{array}$ & t-value & $\begin{array}{l}\text { Critical } \\
\text { Value }\end{array}$ & $\begin{array}{l}\text { Coefficient } \\
\text { Parameter }\end{array}$ & $\begin{array}{l}\text { Direct } \\
\text { Effect }\end{array}$ & $\begin{array}{c}\text { Indirect } \\
\text { Effect }\end{array}$ & $\begin{array}{c}\mathbf{R} \\
\text { Square } \\
\end{array}$ & Conclusion \\
\hline $\begin{array}{c}\text { Price Perception - } \\
\text { Consumer Trust }\end{array}$ & 45,5776 & 1,96 & 0,7756 & $60,16 \%$ & - & $60,2 \%$ & $\begin{array}{c}\text { Ho rejected, H1 } \\
\text { accepted }\end{array}$ \\
\hline $\begin{array}{l}\text { Consumer Trust - } \\
\text { Purchase Intention }\end{array}$ & 10,9761 & 1,96 & 0,4995 & $24,95 \%$ & - & & $\begin{array}{c}\text { Ho rejected, } \mathrm{H} 2 \\
\text { accepted }\end{array}$ \\
\hline $\begin{array}{l}\text { Price Perception - } \\
\text { Purchase Intention }\end{array}$ & 9,0384 & 1,96 & 0,4101 & $16,82 \%$ & - & $73,5 \%$ & \\
\hline $\begin{array}{l}\text { Price Perception - } \\
\text { Consumer Trust - } \\
\text { Purchase Intention }\end{array}$ & 47,5554 & 1,96 & 0,7975 & - & $38,74 \%$ & & $\begin{array}{l}\text { Ho rejectea, } \mathrm{H3} \\
\text { accepted }\end{array}$ \\
\hline
\end{tabular}

From the value of $\mathrm{R}$ Square it can be interpreted that $60.2 \%$ of the consumer trust variable is influenced by the price perception variable. In other words, as much as $39.8 \%$ of millennial consumer confidence is influenced by variables other than price which are not examined in this study. Then $73.5 \%$ of the purchase interest variable is influenced by the price perception variable and consumer trust. In other words, as much as $26.5 \%$ of millennial consumer purchase interest is influenced by other variables which are not the focus of this study. Based on all data collected from 400 respondents, all hypotheses are supported that price perception has a positive influence on purchase intention both directly and indirectly through consumer trust.

\section{Hypothesis 1 Test (Effect of Price Perception on Consumer Trust)}

Based on the results of testing the first hypothesis, the t-value is 45.5776 , which is greater than the t-table, which is 1.96 . From the t-count value, it can be stated that the price has an effect on millennial consumer confidence because t-count $>t$-table. Based on partial testing in this study, perceived price has a significant effect on consumer confidence. One of the variables predicted to be able to influence consumer confidence is price perception. The results of this study prove that price perceptions can influence millennial consumer confidence (Oppenheim and Ward, 2006). There is an appeal for independent isolation or "stay at home" from the government with the aim of breaking the chain of spread of the corona virus (Covid-19). This condition has led to changes in routine patterns that are different from restrictions on space and lack of mobility. Consumers will certainly prefer to shop online in such a pandemic situation, so that price is an important determinant in generating confidence in shopping online.

\section{Hypothesis 2 Test (Effect of Consumer Trust on Purchase Intention)}

Based on the results of testing the second hypothesis, the t-value is 10.9761 , which is greater than the t-table, which is 1.96 . From the $\mathrm{t}$-count value, it can be stated that trust has a positive effect on millennial consumer online buying interest because $t$-count $>t$-table. Based on partial testing in this study, trust is proven to have a positive and significant effect on 
purchase intention. Another variable that has an influence on purchase intention is trust. This study proves that trust has a positive and significant effect on millennial customer online buying interest. The results of this study are in accordance with previous studies which prove that trust has an effect on customer buying interest (Mahkota et al., 2014).

\section{Hypothesis 3 Test (Effect of Price Perception on Purchase Intention)}

Based on the results of testing the third hypothesis, the t-value is 9.0384 , which is greater than the t-table, which is 1.96. From the t-count value, it can be stated that the price affects millennial consumers' online buying interest because t-count $>\mathrm{t}$-table. Based on partial testing in this study, price is proven to have a significant effect on purchase intention. One of the variables predicted to be able to influence buying interest is price. The results of this study prove that price perceptions can influence millennial consumer purchase interest. Millennial consumers tend to be more selective in choosing the goods to buy. Millennial customers during the COVID-19 pandemic like this are more sensitive to prices. The results of this study support previous research which states that price has an effect on purchase intention (Thamizhvanan and Xavier, 2012).

\section{CONCLUSION AND SUGESTION}

From the results of this study, it can be concluded that millennial consumers' online purchase interest during the COVID-19 outbreak was influenced by product price perceptions and millennial consumer confidence. These results indicate that efforts to increase interest in buying online can be done by first increasing millennial consumer confidence. Because based on the results of the study, the presence of the mediator variable for consumer confidence, makes the effect of price perception even greater in influencing online buying interest in the midst of this pandemic.

The suggestions that can be given are as follows. First, online shopping should focus more on increasing consumer confidence because the trust effect is stronger than the price effect. Second, the government should work with market place owners to provide subsidies, perhaps through free shipping in the midst of the COVID-19 outbreak to reduce people's activities outside the home. Third, academics and researchers should in future research include new variables that are likely to influence consumer online purchasing interest in the midst of a pandemic situation like now.

\section{REFERENCE}

Abdurrahman, A. S. (2012). Analisis Faktor-Faktor Yang Mempengaruhi Keputusan Pembelian Melalui Social Networking Websites. Fakultas Ekonomi, Universitas Gunadarma.

Algesheimer, R., Dholakia, P., \& Herrmann, A. (2005). The social Influence of Brand Community: Evidence from European Car Clubs. Journal of Marketing, 69(3), 19-34.

Anwar, R., \& Adidarma, W. (2016). Pengaruh kepercayaan dan risiko pada minat beli belanja online. Jurnal Manajemen dan Bisnis Sriwijaya, 14(2), 155-168.

Haryono, S., \& Wardoyo, P. (2012). Structural equation modeling. Bekasi: PT Intermedia Personalia Utama.

Hasan, A. (2014). Marketing dan Kasus-kasus Pilihan, cetakan kedua. Yogyakarta: Caps. 
Kim, M. J., Chung, N., \& Lee, C. K. (2011). The effect of perceived trust on electronic commerce: Shopping online for tourism products and services in South Korea. Tourism Management, 32(2), 256-265.

Koufaris, M., \& Hampton-Sosa, W. (2004). The development of initial trust in an online company by new customers. Information \& management, 41(3), 377-397.

Kusdyah, I. (2012). Persepsi Harga, Persepsi Merek, Persepsi Nilai, dan Keinginan Pembelian Ulang Jasa Clinic Kesehatan (Studi Kasus Erha Clinic Surabaya). Jurnal Manajemen Pemasaran, 7(1), 25-32.

Lee, S., Illia, A., \& Lawson-Body, A. (2011). Perceived price fairness of dynamic pricing. Industrial Management \& Data Systems, 111(4), 531.

Leeraphong, A. M. A.(2013).'Trust and Risk in Purchase Intention through Online Social Network: Focus Group Study of Facebook in Thailand'. Journal of Economics, Business and Management, 1(4).

Lutfie, H., \& Marcelino, D. (2020, September). Implementation Application of Experiential Marketing to Brand Trusts and the Impacts on Purchasing Decisions. In International Conference on Management, Accounting, and Economy (ICMAE 2020) (pp. 211-215). Atlantis Press.

Mahkota, A. P. (2014). Pengaruh Kepercayaan dan Kenyamanan terhadap Keputusan Pembelian Online (Studi Pada Pelanggan Website Ride Inc). Jurnal Administrasi Bisnis, 8(2).

Marcelino, D. (2020). Green Purchase Intention Pada Konsumen Nutrifood di Bandung: Peran Environment Concern Dengan Mediasi Green Trust. Jurnal Sekretaris \& Administrasi Bisnis (JSAB), 4(1), 01-20.

Oppenheim, C., \& Ward, L. (2006). Evaluation of web sites for B2C e-commerce. Aslib Journal of Information Management, 58(3), 237-260.

Rose, S., Clark, M., Samouel, P., \& Hair, N. (2012). Online customer experience in eretailing: an empirical model of antecedents and outcomes. Journal of retailing, 88(2), 308-322.

Saifudin, S. (2019). Pengaruh Iklan Islami Terhadap Minat Beli Calon Konsumen Matahari Dept. Store di Jawa Tengah. Psychology and Marketing, 29(9), 639-650.

Santrock, J. W. (2007). Perkembangan Anak edisi kesebelas. Jakarta: Erlangga.

Setiadi, N. J. (2011). Perilaku konsumen: Konsep dan implikasi untuk strategi dan penelitian pemasaran. Jakarta: Prenada Media.

Taylor, V. A. (2009). Brand name and price cue effects within a brand extension context. Academy of Marketing Studies Journal, 13(2), 59.

Thamizhvanan, A., \& Xavier, M. J. (2013). Determinants of customers' online purchase intention: an empirical study in India. Journal of Indian Business Research, 5(1), 1732.

Toncar, M. F., Alon, I., \& Misati, E. (2010). The importance of meeting price expectations: linking price to service quality. Journal of Product and Brand Management, 19(4), 295-305.

Zikmund, W. G., Carr, J. C., Babin, B., \& Griffin, M. (2013). Business Research Methods. Canada: Nelson Education. 